Vol. 6(6), pp. 215-225, J une 2014

DOI: $10.5897 / J$ ENE2014.0444

Artic le Number: 525578945316

ISSN 2006-9847

Copyright (c) 2014

Journal of Ecology and the Natural Environment

Author(s) reta in the copyright of this a rticle

http://www.academic joumals.org/J ENE

\title{
Hybridization between non-indigenous Oreochromis niloticus and native Oreochromis species in the lower Kafue River and its potential impacts on fishery
}

\author{
Ian Bbole ${ }^{1 *}$, Cyprian Katongo ${ }^{2}$, Andrew M. Deines ${ }^{3}$, Overson Shumba ${ }^{4}$ and David M. Lodge $\mathrm{e}^{4,5}$ \\ ${ }^{1}$ National Aquaculture Research and Development Centre, Mwekera, Kitwe, Zambia. \\ ${ }^{2}$ Department of Biological Sciences, University of Zambia, Lusaka, Zambia. \\ ${ }^{3}$ Department of Biological Sciences, University of Notre Dame, Notre Dame, IN 46556. 574-631-4159, United States of \\ America. \\ ${ }^{4}$ School of Mathematics and Natural Sciences, Copperbelt University, Kitwe, Zambia. \\ ${ }^{5}$ Environmental Change Initiative, University of Notre Dame, United States of America.
}

Received 18 February, 2014; Accepted 17 April, 2014

\begin{abstract}
In the Kafue floodplains, Zambia, a study was done to determine whether meristic and/or other morphological metrics could distinguish putative hybrids (based on color patterns) between nonindigenous Oreochromis niloticus (Nile tilapia) and two native species of Oreochromis andersonii (three spot tilapia) and Oreochromis macrochir (green head tilapia) from the pure parental strains. We also surveyed local fishermen to document their knowledge and beliefs on the spread of $O$. niloticus in the last decade, the occurrence of hybridization, and any changes in catch per unit effort of these and other species. A sample of fifty fish specimens were collected for morphometric and meristic data using gill nets and seine nets, and augments by specimens purchased from the catches of local fishermen. A full standard multi-filament net with mesh sizes ranging from 25 to $150 \mathrm{~mm}$ in increments of $12.5 \mathrm{~mm}$ mounted in a fleet was used. The seine net used was of $25 \mathrm{~mm}$ mesh size, approximately $100 \mathrm{~m}$ long and $2 \mathrm{~m}$ high at the pocket. We analyzed the morphological and meristic data using the program STATISTICA. Our results confirm that: in the last decade, $O$. niloticus has spread throughout the Kafue floodplains from its initial site of introduction near the eastern end of the Kafue floodplain; putative hybrids between $O$. niloticus and $O$. andersonii cannot be distinguished from parental species based on morphometric or meristic traits; and survey results of local fishermen indicate that they have experienced increases in catch per-unit- effort of 0 . niloticus while simultaneously experiencing decreases in catch per-unit-effort of native tilapia.
\end{abstract}

Key words: Indigenous knowledge (IK), hybridization, native, invasive species, morphometrics, meristics, Kafue River.

\section{INTRODUCTION}

In Zambia, subsistence and commercial fish catches are important for social and economic development of communities and the nation. The fisheries sector contributed $1.24 \%$ to the Gross Domestic Product (GDP) bet- 
ween 2002 and 2007 (Musumali et al., 2009) equivalent to US\$51- 135 million per annum. The fishery sector plays a pivotal role in the economy through employment especially to the rural poor and provides an affordable animal protein source for many households in Zambia. Over 300,000 people in Zambia earn their income directly as fishers and fish farmers or indirectly as traders, processors and other service providers (Musumali et al., 2009).

The production of fish from aquaculture has been on a steady increase globally. Aquaculture has been noted to be one of the fastest growing food-producing systems in the world (Ahmed and Lorica, 2002). Tilapia culture has seen a rapid global expansion especially in developing countries (El- Sayed, 2006) and it is practiced in over 100 countries globally (FAO, 2004). Due to the environmental challenges associated with terrestrial agriculture, tilapia culture has been promoted as an important source of animal protein that could provide food security especially for developing countries (Canonico et al., 2005). In 2010, approximately 32 million tonnes of farmed tilapia was produced worldwide (FAO, 2012). Oreochromis niloticus (Nile tilapia) and its hybrids comprise approximately $80 \%$ of the total tilapia aquaculture production in the world (FAO, 2006). While global tilapia production contributes substantially to economic development, the escape or release of tilapia into the waters outside their native range is a concern for a number of reasons (Canonico et al., 2005).

Introduced tilapia species, typically of the genus Oreochromis, which establish feral populations can cause adverse ecological impact such as the competition with the native species for food, breeding sites and habitats (Canonico et al., 2005). They may also cause eutrophication especially in intensive tilapia culture due to release of excreta into the water and spread pathogens and parasites to native fish species (Starling et al., 2002; Dabbadie and Lazard, 2010). These factors may cause reduction in biodiversity of the receiving ecosystem and population of native fish species. When formerly isolated tilapia species are brought into contact through introduction mediated by aquaculture, hybridization with closely related native species may occur and have negative genetic impacts by the production of hybrids in the population (D'Amato et al., 2007). This may threaten or even eliminate pure native wild populations that are important genetic resources for future aquaculture breeding programs (Lind et al., 2012). Furthermore, reduced fecundity has been reported in some hybrids, which may eventually lead to lower fish yields (Amarasinghe and De Silva, 2010).

In addition to aquaculture, tilapias have been introduced for biological control of aquatic weeds and insects, as bait for capture fisheries and for re-stocking of capture fisheries (Canonico et al., 2005). Among the tilapias introduced in many parts of Africa, O. niloticus (Nile tilapia) and its hybrids account for over $90 \%$ of the production (Senanan and Bart, 2010). Since its introduction in Lake Victoria in the 1950s, it has spread to Eastern and Southern Africa as far as the Limpopo River in South Africa due to intentional introduction especially for aqua-culture purposes (Wise et al., 2007). Several reports indicate that in many freshwater systems in Africa where Nile tilapia has been introduced and has established itself and is productive, it has completely eliminated the native Oreochromis species (Shipton et al., 2008). Oreochromis niloticus has become invasive in many water and wetland systems as a result of intentional introductions or escapes from aquaculture facilities (Gupta et al., 2004). In Lake Victoria, for example, the introduction of Nile tilapia completely eliminated Oreochromis esculentus within a period of 30 years (Goudswaard et al., 2002; Wise et al., 2007). The establishment of feral populations of Nile tilapia in an ecosystem is almost impossible to control and the only way to reduce the impact of this species is to prevent its entry into new freshwater habitats (Wise et al., 2007).

According to Schwanck (1995), O. niloticus ((locally known as 'Namadama' (fish from the dams) or 'Wamunyima' (name of the manager at Zambia Sugar Estate who kept the fish) was imported together with Oreochromis aureus from the University of Stirling in 1982 and in 1988 and introduced into the Kafue catchment area by the Zambia Sugar Estate. However, by 1990 O. aureus had disappeared because it did not breed well. At the same time, Kafue Fisheries Ltd cultured the $O$. niloticus further down the Kafue River. Utsugi and Mazingaliwa (2002) reported that during the flood of 1989, fish escaped into the Kafue River. The first catches of Nile tilapia were reported in 1992 in the Kafue River (Shipton et al., 2008), and were spreading in 1994 (Schwanck, 1995).

The presence of introduced $O$. niloticus in the Kafue River, and its hybridization with at least two native species (Oreochromis andersonii and Oreochromis macrochir), has been documented with genetic analysis (Deines et al., 2014). In particular, individuals with both the vertically barred tail of $O$. niloticus and the lateral black spots of $O$. andersonii were confirmed to be hybrids between the two species (Figure 1D). In this paper, we extended these results by: surveying local fishermen to qualify their assessment of the occurrence of $O$. niloticus and hybrids in the Kafue floodplain, and their assessment of any changes in catch-per-unit-effort of $O$. niloticus and native species; and test whether putative hybrids (with both the barred tails and lateral spots) can also be distinguished

${ }^{*}$ Corresponding author. E-mail: ibbole@gmail.com.

Author(s) agree that this article remain permanently open access under the terms of the Creative Commons Attribution License 4.0 International License 


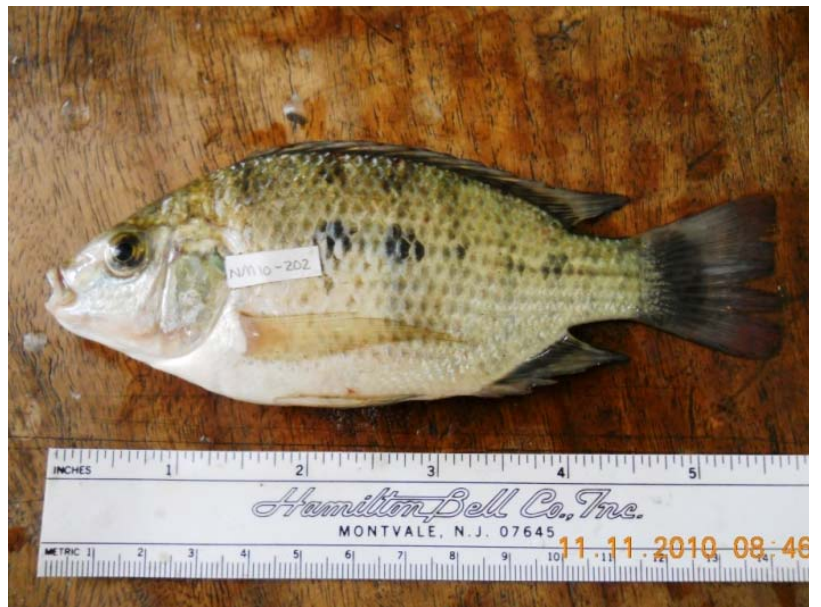

A

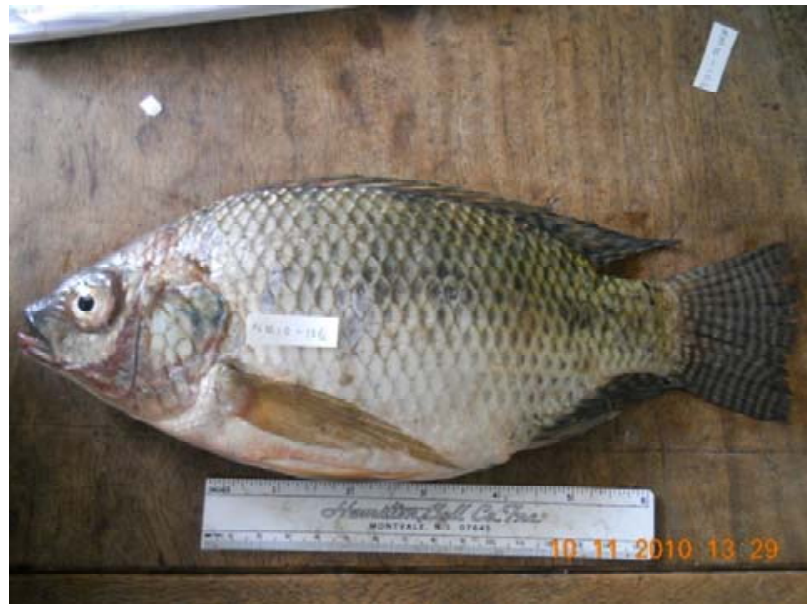

C

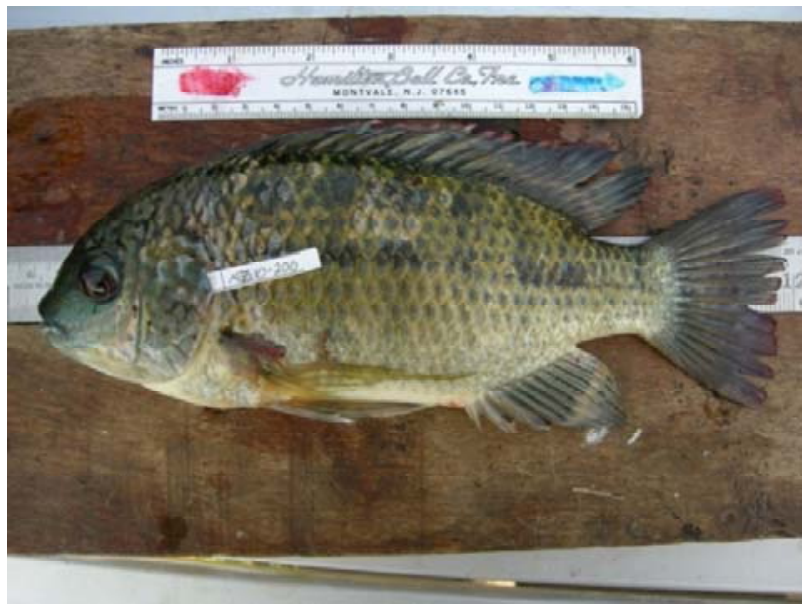

B

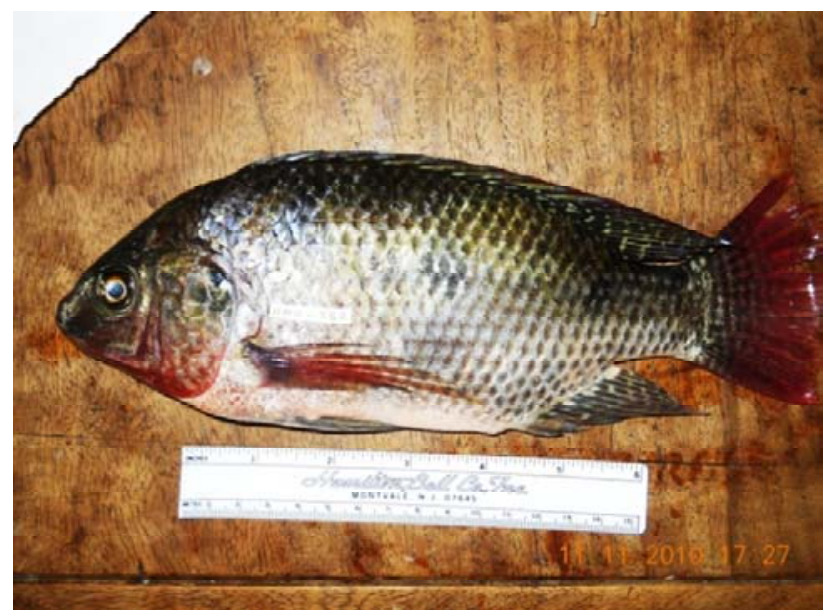

D

Figure 1. Fish species: (A) Oreochromis andersonii, (B) Oreochromis macrochir, (C) Oreochromis niloticus, (D) Putative hybrid (O. andersonii x $O$. niloticus).

from parental species on the basis of morphometric or meristic traits.

\section{METHODS}

\section{Study area}

The Kafue River system supports an extensive fishery in Zambia. It covers a stretch of about $1,576 \mathrm{~km}$ and an area of $152,000 \mathrm{~km}^{2}$. The Kafue flood plains themselves are $250 \mathrm{~km}$ long and $60 \mathrm{~km}$ wide covering an area of approximately $6,500 \mathrm{~km}^{2}$ (Figure 2) (Chabwela and Mumba, 1988). The Kafue fishery is mainly exploited by artisanal fisherfolks using fibre glass and dug-out canoes. They use a variety of fishing nets such as gill nets and seine nets as well as hooks to catch fish. Their nets range in size from 1" - 7" $(2.54 \mathrm{~cm}-$ $17.78 \mathrm{~cm}$ ) mesh. Illegal fishing methods are very common such as the use of explosives and 'Kutumpula' bashing water to drive fish towards the nets.
The fish species composition of ten most important fish species in the Kafue fishery for the period 1985 to 2005 included: Clarius gariepinus, Schilbe intermedius, Marcusenius macrolepidotus, Serranochromis angusticeps, Serranochromis macrocephalus, Oreochromis andersonii, Clarius ngamensis, Synodontis kafuensis, Hepsetus odoe and Sargochromis condringtoni (Nyimbili, 2006). Over the years, there has been a decrease in catch per unit effort of these species.

\section{Interviews of fishermen}

With the approval of the Zambian Department of Fisheries, and following the approach of Schwanck (1995), we conducted interviews on 14 fishermen in 7 of the sampling sites (Choongo, Musa Gate, Chitobolo, Namwala, Nyimba, Kapongo and Cheba) (Figure 2) to qualify their assessment of how the occurrence of $O$. niloticus changed over time, and any changes in catch-per-effort of $O$. niloticus and native species. Fishermen were selected with the aid of local authorities who identified them as experienced and 


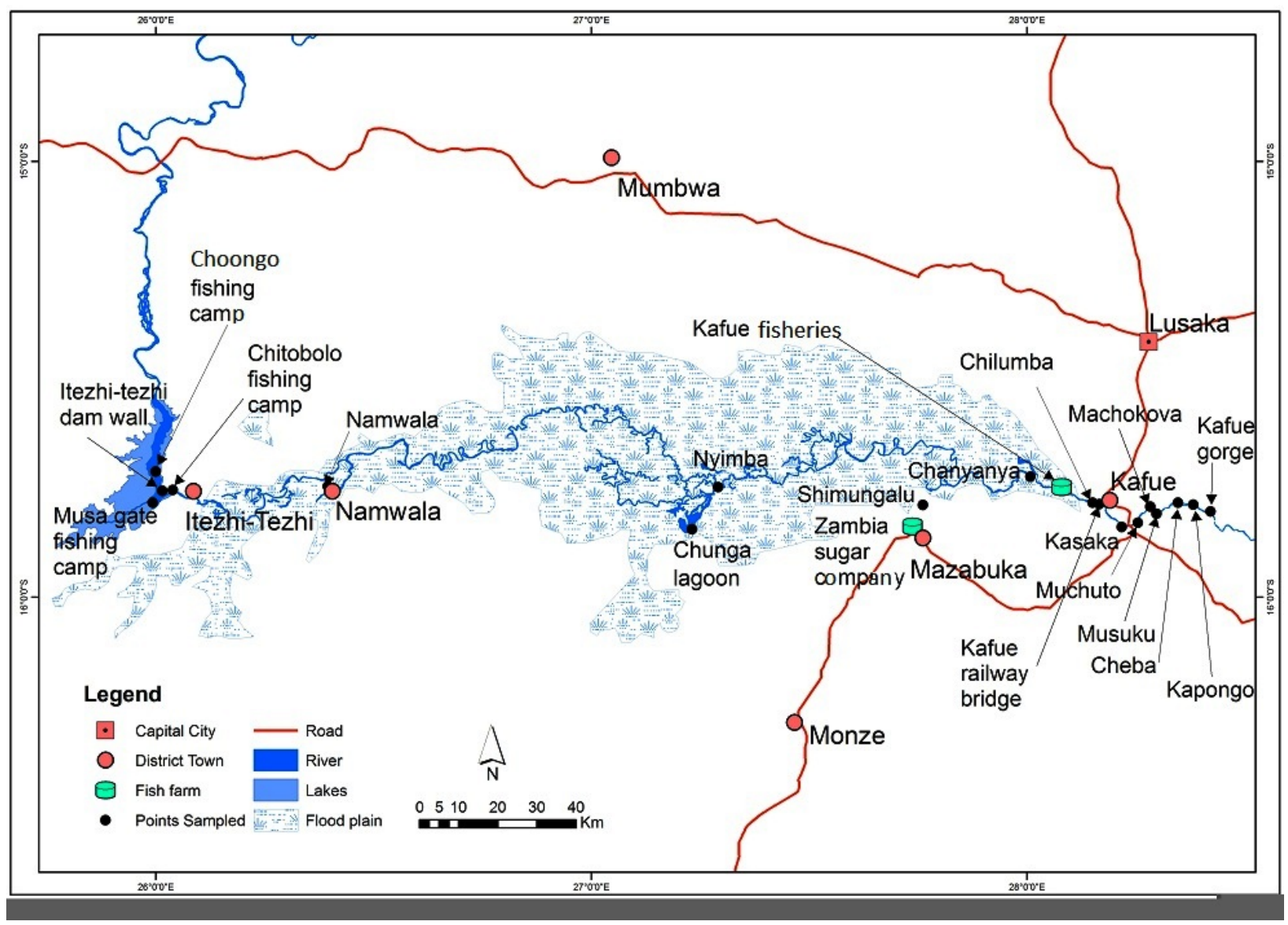

Figure 2. Fishing camps and actual sites sampled on the Kafue floodplains.

having been in the industry for more than 10 years. The questionnaire was administered in the local dialect and the responses were written by the questioners who included the author and the local fishery personnel. The responses used in this paper were: the person's fishing location, fishing method, type of species targeted, what species they have observed to be increasing or decreasing. The questionnaires were also designed to find out how much information the fishermen had on $O$. niloticus. The information on $O$. niloticus included; whether they have caught the species before, which year they made their first catch if they have caught it before, the catch per effort of the species and whether they have observed any changes in the catch per effort of native Oreochromis species since its introduction.

\section{Fish sampling}

Sampling was done in six sites and additional samples were collected from fishermen in four other different sites. Oreochromis niloticus, $O$. macrochir and $O$. andersonii were identified using Skelton (2001). The putative hybrids were identified as individuals with the distinct vertical stripes of $O$. niloticus on the caudal fin and either the three or four conspicuous black mid-lateral blotches of $O$. andersonii or the steep rounded head profile of $O$. macrochir (Trewavas, 1983) (Figure 1).

A total of 50 individuals were sampled for morphometric measurements and meristic counts from 10 sampling sites along the length of the Kafue floodplains (Figure 2 and Table 1). Oreochromis niloticus had previously been detected at some of the sampling sites (Schwanck, 1995). Sites at Choongo and Musa Gate are above the Itezhi-tezhi Dam where there is no indication that $O$. niloticus is present.

Samples of Oreochromis species were collected using a standard gillnet survey, seine nets and from fishermen during the 2010 low-water season (August-September). Gillnets set was carried out for three consecutive nights in six sampling sites. A full standard multi-filament net with mesh sizes of $25,37.5,50,62.5,75,87.5$, $100,112.5,125,137.5$ and $150 \mathrm{~mm}$ mounted in a fleet was used. Each net used measured $45 \mathrm{~m}$ and the fleet used was, therefore $495 \mathrm{~m}$ long. The setting of the nets was done at approximately 6 $\mathrm{pm}$ and removed the following day at $6 \mathrm{pm}$.

Fish samples were supplemented using beach seine nets at Choongo and Namwala sites. The seine net used was of $25 \mathrm{~mm}$ mesh size, approximately $100 \mathrm{~m}$ long and $2 \mathrm{~m}$ high at the pocket and was dragged by six men over a period of about 20 to $30 \mathrm{~min}$. Two hauls were made consecutively. Other fish samples were collected from the local fishermen after carefully studying their catches. Most of their catches were mainly from seine nets. Collections supplemented from fishers took place at Chitobolo, Chilumba, Kasaka and Kapongo (Figure 2).

A colour photograph of each fish sampled was taken. Each fish was then individually placed in a polythene bag and preserved in $10 \%$ formalin in $20 \mathrm{~L}$ buckets according to species for further processing as described below.

\section{Morphometric measurements and meristic counts}

Morphometric measurements and meristic counts of each fish were obtained according to methods of Barel et al. (1977) and Snoeks 
Table 1. Fish sampled for morphometric measurements and meristic counts

\begin{tabular}{|c|c|c|c|}
\hline Specie & Sampling site & $\begin{array}{l}\text { Total length } \\
\text { range }(\mathrm{mm})\end{array}$ & $\begin{array}{l}\text { Total fish } \\
\text { sampled }\end{array}$ \\
\hline Oreochromis andersonii & $\begin{array}{l}\text { Choongo, Namwala, Chunga lagoon, Nyimba, Shimungalu, } \\
\text { Chanyanya, Kasaka, Kapongo }\end{array}$ & $141-274$ & 18 \\
\hline Oreochromis macrochir & $\begin{array}{l}\text { Namwala, Chunga lagoon, Nyimba, Shimungalu, Chilumba, } \\
\text { Kasaka }\end{array}$ & $69-380$ & 14 \\
\hline Oreochromis niloticus & Chitobolo, Chunga lagoon, Nyimba, Shimungalu, Chilumba & $122-256$ & 12 \\
\hline $\begin{array}{l}\text { Putative } O \text {. andersonii } \times 0 \text {. } \\
\text { niloticus }\end{array}$ & Namwala, Shimungalu, Kapongo & $192-246$ & 6 \\
\hline
\end{tabular}

(1994). These measurements were taken using a vernier calliper to the nearest 0.01 . The meristic counts were done under a dissecting microscope.

The morphological measurements taken were: Lachrymal depth (LacrD) defined as preorbital depth (POD), snout length (SnL), lower jaw length (LJL), premaxillary pedicel length (PPL), cheek depth (ChD), horizontal eye diameter/eye depth (EyD), vertical eye diameter/eye length (EyL), inter-orbital width (IOW), head width $(H W)$, head length $(H L)$, standard length $(S L)$, body depth $(B D)$, dorsal fin base length (DFB), anal fin base length (AFB), pectoral fin base length (PFL), predosal distance (PrD), prepelvic distance $(\mathrm{PrP})$, prepectoral distance/preventral distance (PrV), preanal distance $(\operatorname{PrA})$, caudal peduncle length $(\mathrm{CPL})$, caudal peduncle depth (CPD)

The meristic counts taken included: the upper and lower jaw teeth numbers (UJT and LJT), inner tooth rows, dorsal fin spiny rays (DSPIN) and dorsal fin soft rays (DSOFT), anal fin spiny rays (ASPIN) and anal fin soft rays (ASOFT), upper and lower lateral line scales (ULL and LLL), lateral line to anal fin scales (LLA), pelvic/ventral fin scales (PV), number of scales between the dorsal fin and the upper lateral line (DLL), scales around the caudal peduncle $(\mathrm{CP})$ and cheek scales $(\mathrm{CK})$.

\section{Data analysis}

\section{Interviews}

The information provided by the fishermen on the questionnaires was analysed to reveal the general understanding the fishermen had on introduction of $O$. niloticus. We found this was possible because Nile tilapia were easily distinguished by fishermen from other tilapia by the presence of stripes on the caudal fin, a characteristic not possessed by other species of tilapia (Trewavas, 1983).

\section{Morphometric and meristic data handling}

The morphometric and meristic data were analyzed using STATISTICA Version 5 (StatSoft, Inc., 1997). The raw morphometric data were transformed into logarithms and subjected to PCA to extract principle components.

The data were then used to plot relationships among the fish species based on principal component (PC) 2 and PC 3. Principal component 1 was not used in morphometric analysis because in multivariate allometry PC 1 represents the size and shape as all the characters are correlated positively with this component (Lleonart et al., 2000). Meristic count data where analyzed based on PC 1 and 2. This is because meristic counts are not influenced by allometry on PC 1. The factor loading was used to identify which of the morphometric and meristic characters were causing most variations among the fish.

\section{RESULTS}

\section{Distribution of Oreochromis species in the Lower Kafue River}

The invasive species $O$. niloticus was found along the whole $250 \mathrm{~km}$ stretch of the Kafue floodplains. It was however, absent in the stretch of the Kafue River upstream of the Itezhi-tezhi Dam during this study. The local fishermen also confirmed that they had not caught $O$. niloticus in the Kafue River upstream the Itezhi-tezhi Dam wall. They also indicated that their first catch of $O$. niloticus on the Kafue River below the Itezhi-tezhi Dam wall was around the year 2002. The information from the local fishermen indicated that by 2004 O. niloticus was present in all areas in the Kafue floodplain.

During this study, $O$. niloticus catch was higher than both $O$. andersonii and $O$. macrochir catches for almost all the sampling done using both seine and gill nets. Our observations of a subset of catches by fishermen were consistent with the pattern reported by the fishermen: $O$. andersonii was the least frequent in most of the catches. In Shimungalu, Chunga lagoon and Nyimba, O. andersonii was very rare.

\section{Survey results}

Twelve of the fishermen interviewed were using dug-out canoes as fishing vessels while two were using small engine boats. They were using both seine nets and gill nets with mesh sizes ranging mainly between $1-31 / 2$ inches $(25.4$ to $88.9 \mathrm{~mm})$.

All the fishermen interviewed were aware of the presence of O. niloticus. By 2004, O. niloticus had spread upstream as far as the Itezhi-tezhi Dam and downstream to Kapongo (Kafue Gorge Dam) (Table 2). All except one of the fishermen interviewed reported observing high catch-per-effort of $O$. niloticus in their fishing areas, and the species is among the three most targeted fish species, 
Table 2. Results from interviews of fishermen conducted during the study. Sites are ordered from west to east (see Figure 2)

\begin{tabular}{|c|c|c|c|c|c|c|}
\hline Site & $\begin{array}{c}\text { Number of fishermen } \\
\text { interviewed }\end{array}$ & $\begin{array}{l}\text { Type of fishing } \\
\text { vessel }\end{array}$ & $\begin{array}{l}\text { Type of } \\
\text { nets used }\end{array}$ & $\begin{array}{l}\text { Mesh size } \\
(\mathrm{mm})\end{array}$ & $\begin{array}{c}\text { Year started } \\
\text { fishing }\end{array}$ & $\begin{array}{l}\text { First catch of } \\
\text { O. niloticus }\end{array}$ \\
\hline Choongo & 1 & Dug-out canoes & - & - & - & No O. niloticus \\
\hline Musa gate & 1 & Dug-out canoes & - & - & - & No O. niloticus \\
\hline Chitobolo & 1 & Dug-out canoe & & & - & 2002 \\
\hline Namwala & 5 & Dug-out canoes & $\begin{array}{l}\text { Seine nets } \\
\text { Gill nets } \\
\text { Hooks }\end{array}$ & $11 / 4 . "-31 / 2$ & $\begin{array}{l}1979,1994 \\
2004\end{array}$ & $\begin{array}{l}\text { 1996, 2001, } \\
2004\end{array}$ \\
\hline Nyimba & 4 & $\begin{array}{l}\text { Small engine } \\
\text { Fibre glass } \\
\text { Dug-out canoes }\end{array}$ & $\begin{array}{l}\text { Seine, Gill } \\
\text { Rod and } \\
\text { line }\end{array}$ & $1.0^{\prime \prime}-6.0^{\prime \prime}$ & $\begin{array}{l}1976,1992 \\
1994\end{array}$ & $\begin{array}{l}1994,2000 \\
2001\end{array}$ \\
\hline Cheba & 1 & Dug-out canoes & Seine & $1 \frac{11 / 4 . "}{}$ & 1978 & 1995 \\
\hline Kapongo & 1 & Dug-out canoes & Seine & $11 / 4 . "$ & 1982 & 2004 \\
\hline
\end{tabular}

and among the three most commonly caught species together with Tilapia rendalii and Barbus species (Figure 3).

Oreochromis niloticus was one of the fish species that fishermen reported increasing in catch-per-effort together with Redbreast tilapia ( $T$. rendalii) (Figure 4). Fishermen identified $O$. andersonii and $O$. macrochir as fish species for which the catch-per-effort had declined (Figure 4). Fishermen reported catching fish possessing features of both $O$. niloticus and $O$. andersonii, suggesting potential hybridization between these species.

\section{Morphometric and meristic results}

A total of 50 specimens sampled from the Kafue floodplain were assigned species identification according to morphology and colour patterns: $O$. niloticus, $O$. andersonii, O. macrochir and putative hybrids between $O$. niloticus and $O$. andersonii.

Overall, the PCA results provided clear discrimination among the three parental species, but the putative hybrids always clustered with $O$. niloticus. PCA results distinguished $O$. andersonii from $O$. niloticus on PC 2 although a few individuals from both species overlap. Oreochromis andersonii is similar to $O$. macrochir. On PC 3, O. macrochir is different from $O$. andersonii but similar to $O$. niloticus and the putative hybrids.

The three morphometric characters that showed most significant variations between putative species along PC 2 included: Premaxillary pedicel length (0.4007), lower jaw width $(-0.3492)$, and caudal peduncle length (0.2876 ). The variations between species along PC 3 were mainly due to: vertical eye diameter/eye lengthy ($0.2987)$, horizontal eye diameter/eye depth $(-0.2762)$ and anal fin base length (0.2357) (Figure 5).

The meristic results indicate that the fish species could only be separated on PC 2 where $O$. macrochir is different from both $O$. andersonii and $O$. niloticus and the putative hybrids. Again, the putative hybrids clustered together with $O$. niloticus.

The three meristic characters that showed the most significant variations along the PC 1 include: Upper lateral line scales (0.8293), anal fin soft rays $(0.7688)$ and lower lateral line scales $(0.6555)$. On PC 2 they include: Number of scales between the anal fin and upper lateral line $(-0.3971)$, caudal peduncle scales $(-0.3249)$ and dorsal fin soft rays $(0.3038)$ (Figure 6$)$.

\section{DISCUSSION}

\section{Indigenous knowledge of the distribution of 0 . niloticus}

This study has revealed that $O$. niloticus is now distributed along the whole of the $250 \mathrm{~km}$ stretch of the Kafue floodplains. Schwanck (1995) survey found O. niloticus confined within a stretch of $75 \mathrm{~km}$ between Muchuto and Kachola in the eastern region of the floodplain. However, he rightly predicted that $O$. niloticus would expand its range upstream, being finally restricted by the Itezhi-tezhi Dam wall. The sampling done at Choongo upstream before the dam wall and the study of the fishermen catches at Musa Gate also before the dam wall revealed no presence of $O$. niloticus. This means that the dam wall has acted as a geographical barrier preventing further spread of the $O$. niloticus upstream.

The sampling conducted during this study at different sites and the study of tilapia catches from fishermen along the floodplain showed higher catches of $O$. niloticus followed by $O$. macrochir and $O$. andersonii which was least. A study by Chikopela et al. (2011) in three major habitats of the Kafue floodplains revealed that $O$. niloticus had the highest index of relative importance (IRI) and contributed most to the diversity and evenness of the floodplain as compared to $O$. andersonii and $O$. macrochir. Oreochromis niloticus had not only established its popu- 


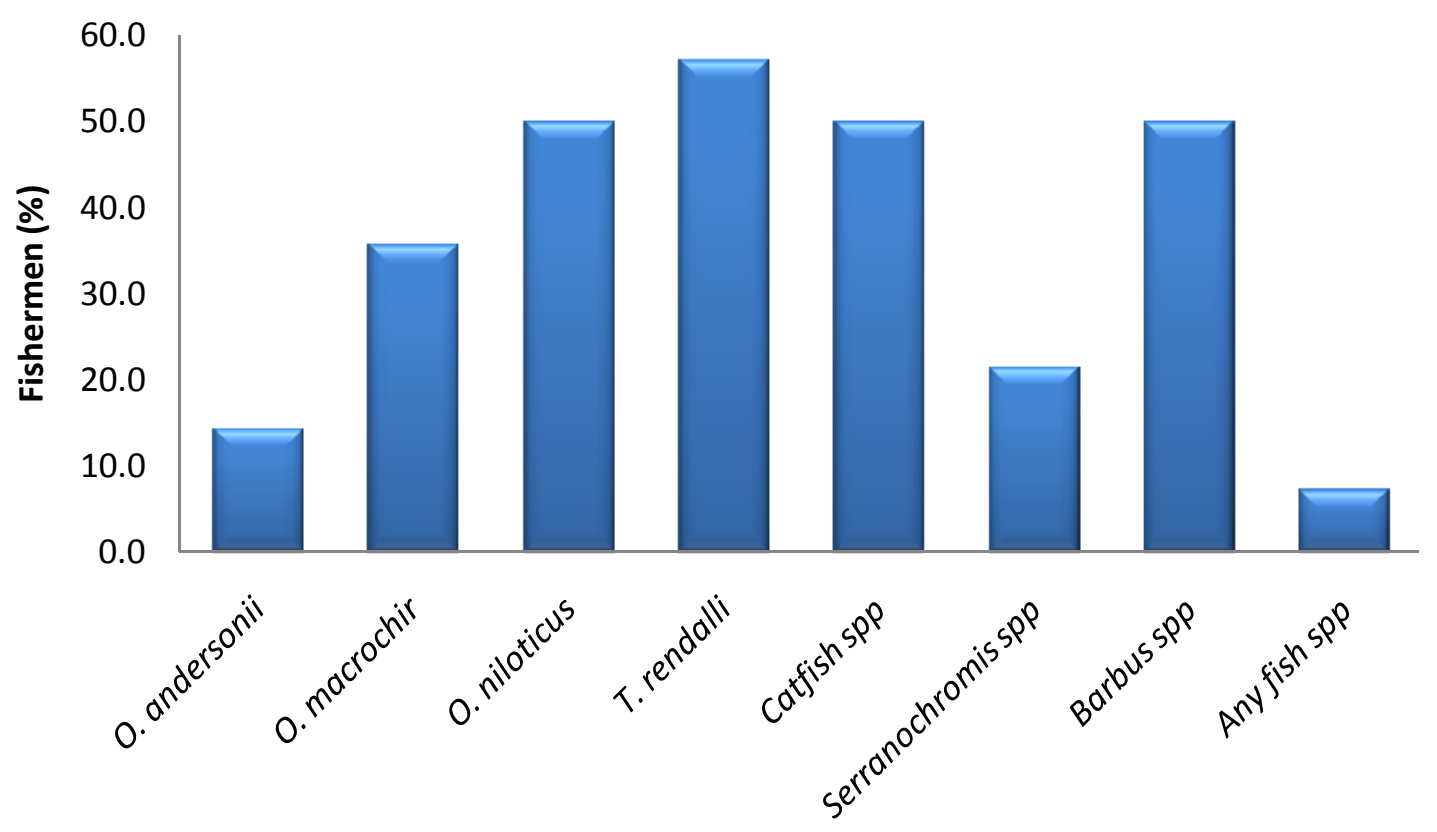

Fish species

Figure 3. Fish species caught by local fishermen interviewed.

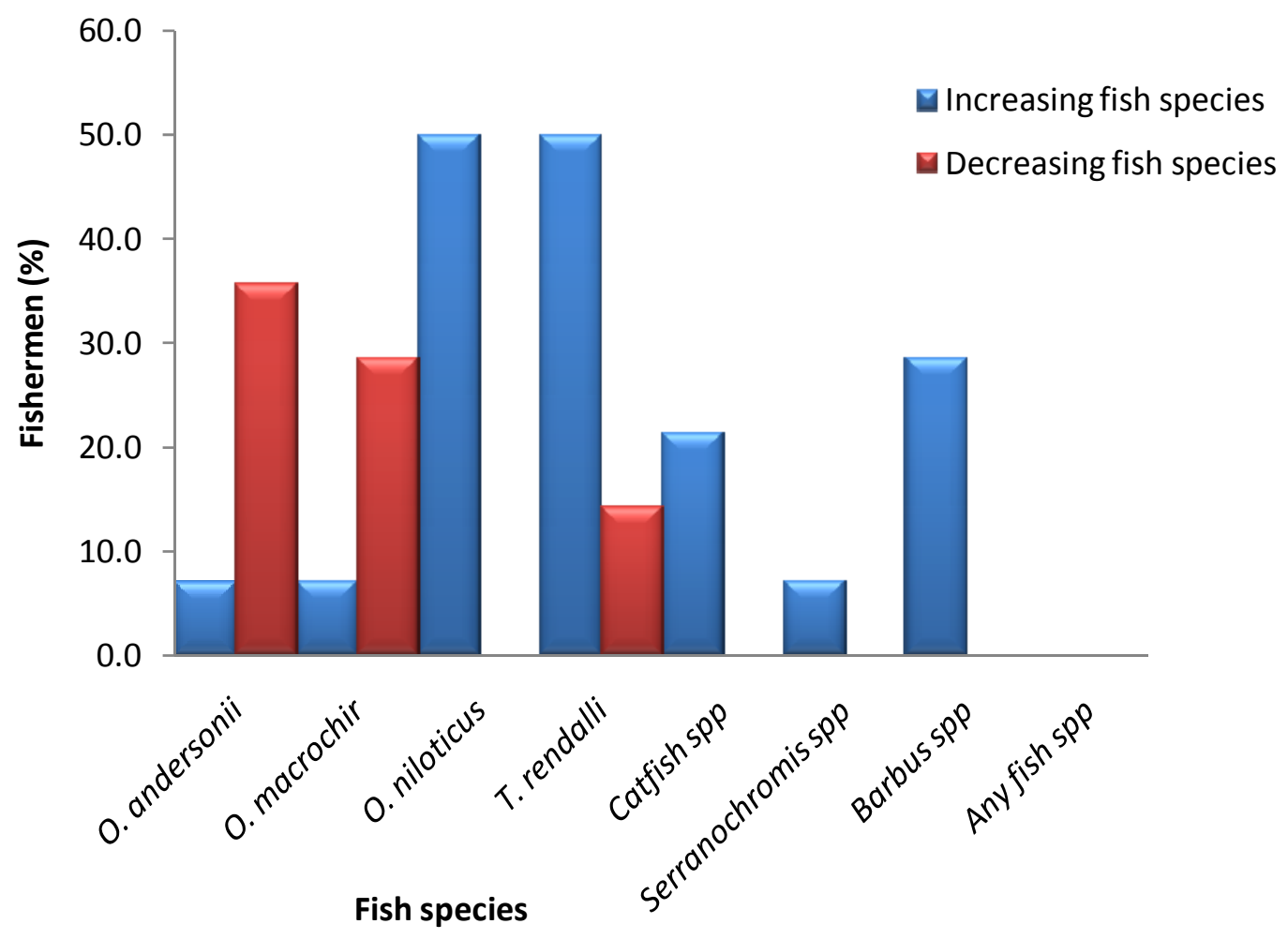

Figure 4. Increasing and decreasing fish species as reported by the local fishermen interviewed.

lation in the Kafue but has dominated the numbers among the mouth brooding tilapiines (Chikopela et al., 2011). The local fishermen interviewed have also repor- ted a decrease in catch-per-effort of both O. macrochir and $O$. andersonii catches since the introduction of $O$. niloticus. This seems to indicate that the introduction of 


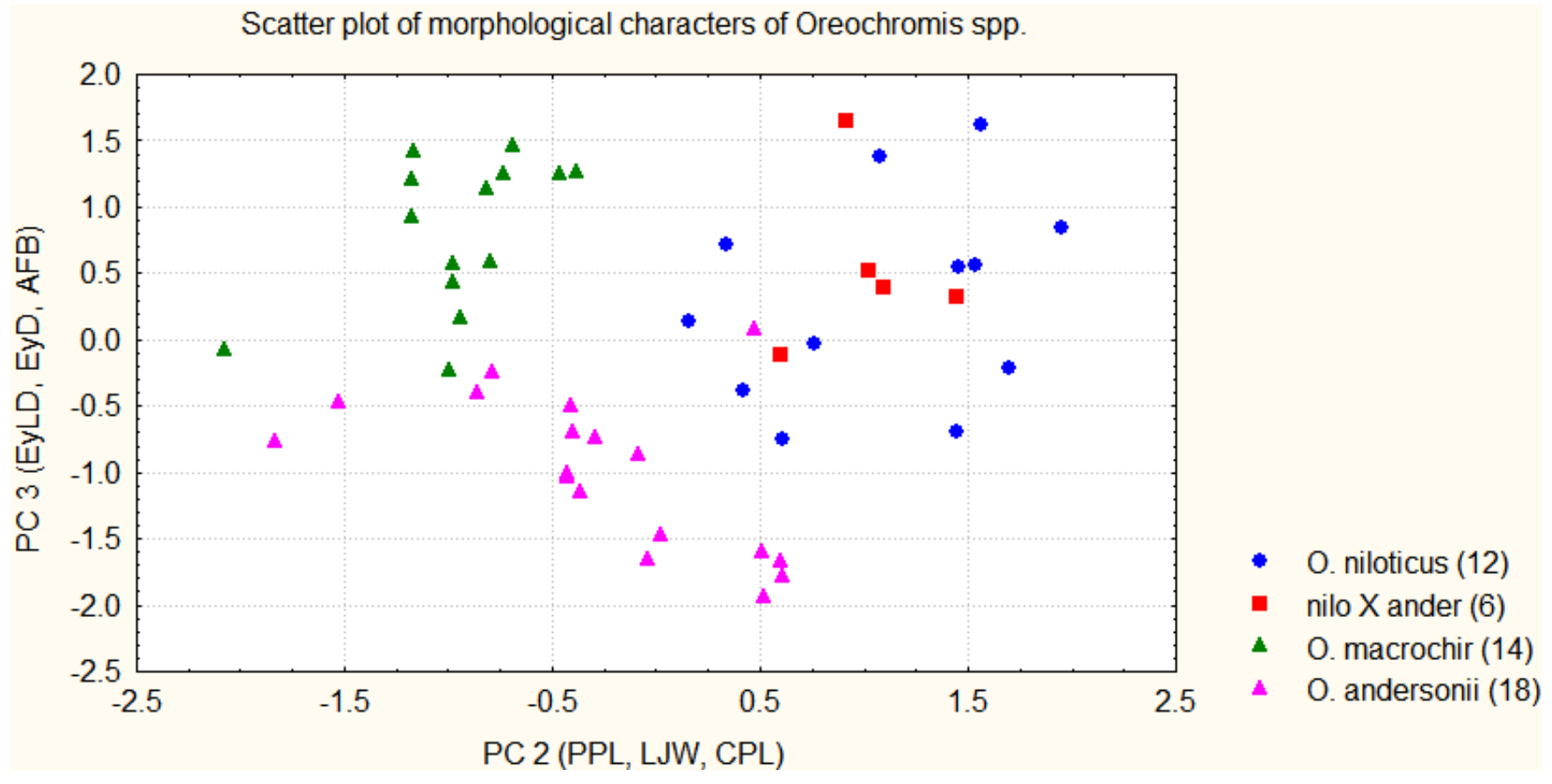

Figure 5. PCA plot of morphometric characters of $O$. niloticus, O. andersonii and O. macrochir including suspected hybrids. Each data point represents an individual fish. $\mathrm{PPL}=$ Premaxillary pedicel length, $\mathrm{LJW}=$ lower jaw width, $\mathrm{CPL}=$ caudal peduncle length, EyLD = vertical eye diameter/eye lengthy, EyD = horizontal eye diameter/eye depth, AFB = anal fin base length.

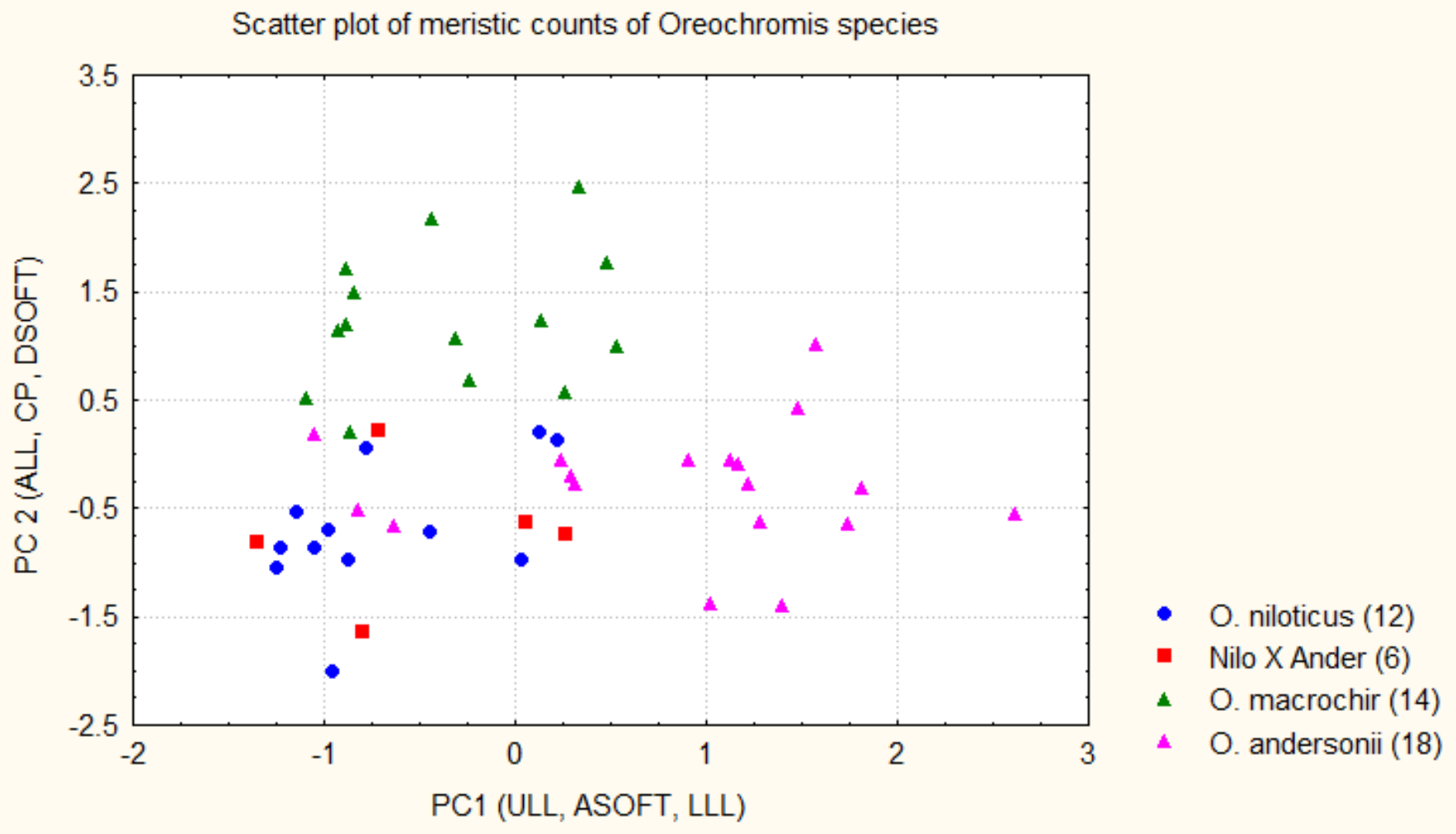

Figure 6. PCA plot for meristic counts of $O$. niloticus, $O$. andersonii and $O$. macrochir including suspected hybrids. Each data point represents an individual fish. ULL = Upper lateral line scales, ASOFT = anal fin soft rays, LLL = lower lateral line scales, $A L L=$ number of scales between the anal fin and upper lateral line, $\mathrm{CP}=$ caudal peduncle scales, DSOFT = dorsal fin soft rays. 
the non-indigenous $O$. niloticus may have an impact on the population of other related species like $O$. macrochir and $O$. andersonii. This assumption may not be conclusive since sampling was not done throughout the year. In addition, fishing pressure, introduction of non-indigenous crayfish (Cherax quadricarinatus) which three of the fishermen reported, or other unmeasured factors could contribute to the decline in catch-per-effort of native fishes during the spread of $O$. niloticus.

Taken at face value, however, the reduction in catches of $O$. andersonii reported by fishermen, and its apparent absence in areas closest to the point of release of $O$. niloticus like Shimungalu in Mazabuka indicate a strong negative interaction with $\mathrm{O}$. niloticus leading to the establishment of the non-indigenous species at the expense of the indigenous species. The probable explanation of this is the potential of $O$. niloticus to hybridize with other Oreochromis species followed by the extinction of the hybrids leaving only pure O. niloticus strains (Shipton et al., 2008). The takeover is usually preceded by a period of introgressive hybridization (Schwanck, 1995).

Some fishermen reported that they had seen $O$. niloticus individuals possessing features of other native Oreochromis species, especially the three or four spots of $O$. andersonii consistent with the hybridization confirmed by Deines et al. (2014).

While the socio-economic impact arising from the introduction of $O$. niloticus in the Kafue floodplains was not investigated fully in this study, the fishermen interviewed had different views on the effect of $O$. niloticus on their catches. Among the fishermen interviewed, $41.7 \%$ of them felt that $O$. niloticus has affected their catches of native tilapia while $33.3 \%$ said it did not. Another $25 \%$ of fishermen interviewed did not know whether there was an effect or not. The fishermen claimed that the introduction of $O$. niloticus has reduced their sales of native tilapia which are one of the most preferred fish in Zambia which also fetch a higher cost. This is because they are not able to catch large quantities of native tilapia as they used to before $O$. niloticus was introduced. Some felt that their income has reduced because $O$. niloticus cannot be preserved for a longer time as compared to the native tilapia. Some fishermen interviewed confirmed that they have resorted to the use of bad fishing methods like 'bashing' the water to drive fish to the set nets in order to catch native tilapia.

These results suggest that establishment and spread of $O$. niloticus throughout the Kafue floodplains may pose a threat to the ecology and existence of local Oreochromis species. The invasion of $O$. niloticus may also pose a challenge to the sustainability of the fishery and eventually the livelihoods of people dependent on the fishery. This is because a fishery which usually exploits variety of species is more likely to be sustainable than one which depends on only a few species (Dulvy et al., 2000). As long as catch-per-effort of $O$. niloticus remains high, the fishery may be maintained, but perhaps be moving to an
Oreochromis monoculture of $O$. niloticus.

\section{Hybrids identification based on morphometrics and meristics}

Our analysis demonstrated that morphometric and meristic traits are no use in distinguishing hybrids of $O$. niloticus $\times 0$. andersonii from parental individuals. Thus where genetic analysis is not possible future studies on hybridization will have to continue to rely on colour patterns to identify hybrids, while acknowledging that not all hybrids and backcrosses possess the mixed colour patterns (Deines et al., 2014). However, any estimate of the prevalence of hybridization will be poor without genetic analysis, especially because genetic analysis from specimens on the Kafue floodplain revealed hybrid mixture of all the three Oreochromis species, while colour patterns had suggested hybridization involving only $O$. niloticus and O. andersonii (Deines et al., 2014).

\section{Implications}

The issue of food security, dietary and nutritional needs of people in local communities illustrates a concern that goes beyond the potential ecological and genetic impacts on biodiversity of escaped tilapias from aquaculture facilities into receiving ecosystems such as dams, rivers, wetlands or lakes (Seaman and Bart, 2010). As noted by the WorldFish Centre (2009), fish is an important food for over 400 million Africans, contributing essential proteins, minerals and micronutrients to their diets. Zambia is no exception. Fish in Zambia is estimated to provide about $40 \%$ of the animal protein intake. It therefore, plays an important role in the food and nutrition of the Zambian people more especially the urban poor and people living with HIV and AIDS (Musumali et al., 2009).

Taking the case of the Kafue flood plains, fishing is a major mainstay industry for local communities. The observation in this study of the possibility of hybridisation and its potential threats to native fish species that provided food security, employment, economic security, and self-sustenance for this largely rural part of Zambia raises serious concerns. In this fishery, just as in other fishery areas, fishing provides income almost all year round to men, women and youths who cannot find other sources of income.

The results of this study suggest that the presence of $O$. niloticus in the Kafue floodplain has had an impact on the indigenous Oreochromis species. Fishermen reported a reduction in the catch-per-effort of the native Oreochromis species which are commercially important and which are widely favoured by most Zambians. The poverty situation is already apparent in the Kafue floodplains as some of the fishermen interviewed were requesting the government to send them relief food, 
especially during the fish ban period between February and March annually. This is because they cannot catch enough to sustain their families.

Recognising the risks inherent with any species introduction, and the particular risks quantified here on the Kafue floodplain (loss of genetic identity of native tilapia, reported loss of income by fishermen), FAO (1996) advocates that the Precautionary Principal should apply, a consideration relevant to the Zambian Department of Fisheries and similar agencies in other countries to consider with regard to potential future introductions of $O$. niloticus. FAO (2006) recommends that the governments reduce risks of adverse impacts of introduction on capture fisheries to establish corrective or mitigating procedures in advancement of actual adverse effects, and to minimize unintended introduction to wild ecosystems and associated capture fisheries. Loss of native species can lead to loss of genetic diversity necessary for future food security and poverty reduction (Lind et al., 2012). According to Musumali et al. (2009), about $68 \%$ of the Zambian population live below the poverty line. It is more rampant in the rural area were about $81 \%$ live in poverty.

The poverty and food insecurity in Zambia stems from the over reliance on rain-fed agriculture, and associated effects of frequent unfavourable climatic conditions, along with inadequate incomes, access to markets and transport facilities to enable the transfer or purchase of food. This is compounded by low economic diversification into sectors such as fisheries that could supplement crop production. Food security entails the access to enough amounts of safe, nutritious and quality food. For communities in this study, wild fishing is an important if not the most vital activity by which local families meet their food needs and achieve economic security. Anything that disturbs this vital source of nutrition and economic livelihood is likely to embolden poverty, imperil food security, and thwart self-sustenance aspects of their food security.

\section{Conclusion}

This study has revealed that the local fishermen throughout the Kafue floodplain are very aware of the introduction of $O$. niloticus in their fishery. They have reported an increase in catches of $O$. niloticus and associate this increase with the reduction in catches of native $O$. andersonii and $O$. macrochir. Moreover, they have observed apparently hybrid fish that combine characteristics of $O$. niloticus and native Oreochromis species.

There are differences in morphological characters of $O$. niloticus, $O$. andersonii and $O$. macrochir consistent with their classification as different species. However, the hybrids between $O$. niloticus and $O$. andersonii could not be distinguished from $O$. niloticus based on the quantifiable morphometric and meristic measurements.

\section{Conflict of Interests}

The author(s) have not declared any conflict of interests.

\section{ACKNOWLEDGEMENTS}

This part of the broader study leading to the MPhil at the Copperbelt University was made possible through a grant from the NEPAD Agency/ SANBio secretariat under the BioFISA Fish Project. Prof. P.S.M. Phiri supported taxonomy. Department of Fisheries in Kafue, Lochnivar, Namwala and Itezhi-tezhi supported this work; special mention is made of Dr. A. S. Kefi, Mr. J. Mwango. Mr. G. Membele provided the map for the sampling sites.

\section{REFERENCES}

Amarasinghe US, De Silva SS (2010). Impact of Oreochromis mossambicus $x$ O. niloticus (Pisces: Cichlidae) hybridization on population reproductive potential and long-term influence on a reservoir fishery. Fish. Manag. Ecol. 3(3):239-249.

Barel CDN, Van Oijen MJP, Witte F,Witte-Maas ELM (1977). An introduction to the taxonomy and morphology of the haplochromine Cichlidae from Lake Victoria. Netherlands J. Zool. 27:333-389.

Canonico GC, Arthington A, McCrary JK, Thieme ML (2005). The effects of introduced tilapias on native biodiversity. Aquatic Conservation: Marine and Freshwater Ecosystems, 15:463-483.

Chabwela HNW, Mumba W (1998). Integrating water conservation and population strategies on the Kafue Flats. In: de Sherbinin, A., Dompka, V. (Eds.), Water and Population Dynamics. American Association for the Advancement of Science, Washington, DC, USA. Available from

(2004): http://www.aaas.org/international/ehn/waterpop/zambia.htm.

Chikopela ST, Katongo C, Hangoma GM (2011). Abundance of mouth brooding tilapiines in the Kafue floodplains, Zambia. J. Ecol. Nat. Environ. Vol. 3(10), pp. 344-350.

Dabbadie L, Lazard J (2010). Environmental Impact of Introduced Alien Species. http://www.aquatrop.cirad.fr/content/

D'Amato ME, Esterhuyse MM, Waal BCW van der, Brink D, Volckaert FAM (2007). Hybridization and phylogeography of the Mozambique tilapia Oreochromis mossambicus in southern Africa evidenced by mitochondrial and microsatellite DNA genotyping. Conserv. Genet. 8:475-488

Deines AM, Adam Bee C, Katongo C, Jensen R, Lodge DM (2013). The potential trade-off between artisanal fisheries production and hydroelectricity generation on the Kafue River, Zambia. Freshwater Biol. 58(4):640-654.

Deines AM, Bbole I, Katongo C, Feder JL, Lodge DM (2014). Hybridization of native Oreochromis species (Cichlidae) and the introduced Nile tilapia (O. niloticus) in the Kafue River, Zambia. Afr. J. Aquat Sci, 2014, 39(1):23-34

Dulvy NK, Metcalfe JD, Glanville J, Pawson MG, Reynolds JD (2000). Fishery stability, local extinctions and shifts in community structure in skates. Conserv. Biol. 14:283-293.

EI-Sayed, A.F.M. (2006). Tilapia culture. CABI Publishing,UK.

FAO (2004). Fishstat Plus. FAO Rome, Italy.

FAO (2006). Aquaculture Production Statistics 1997-2006. FAO, Rome, Italy.

FAO (2012). The state of world fisheries and aquaculture 2012. FAO, Rome, Italy.

Goudswaard PC, Witte F, Katunzi EFB (2002). The tilapiine fish stock of Lake Victoria before and after the Nile perch upsurge. J. Fish Biol. 60:838-856.

Lleonart J, Salat J, Torres GJ (2000). Removing allometric effects of body size in morphological analysis. J. Theor. Biol. (2000) 205:85-93.

Lind CE, Brummett RE, Ponzoni RW (2012). Exploitation and conservation of fish genetic resources in Africa: issues and priorities for aquaculture development and research. Reviews in Aquaculture. 4(3):125-141

Musumali MM, Heck S, Husken SMC, Wishart (2009). Fisheries in Zambia: An undervalued contributor to poverty reduction. The WorldFish Centre/ The World Bank. Policy Brief 1913.

Nyimbili B (2006). An evaluation of fish population changes in the Kafue 
flats floodplain fishery of Zambia from 1980 to 2005. MSc thesis. University of Bergen, Norway.

Schwanck EJ, (1995). The Introduction of Oreochromis niloticus is spreading on the Kafue floodplains, Zambia. Hydrobiologia, 135, 143147

Senanan W, Bart AN (2010). The potential risks from farm escaped Tilapias. http://media.sustainablefish.org/Tilapia_escapes_WP.pdf

Shipton T, Tweddle D, Watts M (2008). Speciēs Risk Assessment: Introduction of the Nile Tilapia (Oreochromis niloticus) in the Eastern Cape. Eastern Cape Development Corporation.

Skelton P (2001). Freshwater Fishes of Southern Africa. Second edition. Struik Publishers (Pty) Ltd, South Africa.

Snoeks J (1994). The Haplochromines (Teleostei, Cichlidae) of Lake Kivu (East Africa). Ann Museum Royal African Central Sci Zoology. 270:221.

Starling F, Lazzaro X, Cavalcanti C, and Moreira R (2002). Contribution of omnivorous tilapia to eutrophication of a shallow tropical reservoir: evidence from a fish kill. Freshwater Biology. 47:2443-2452.
StatSoft Inc. (1997). STATISTICA for Windows [Computer program manual]. Tulsa, OK: StatSoft, Inc., 2300 East 14th Street, Tulsa, OK 74104, phone: (918) 749-1119, fax: (918) 749-2217, email: info@statsoft.com,WEB: http://www.statsoft.com

Trewavas E (1983). Tilapiine Fishes of the genera Sarotherodon, Oreochromis and Danakilia (p. 583). Ithaca, New York: Cornell University Press.

Utsugi K, Mazingaliwa K (2002). Field guide to Zambian fishes, Planktons and Aquaculture. Japan international Cooperation Agency.

Wise RM, Wilgen BW van, Hill MP, Schulthess F, Tweddle D, ChabiOlay A, HG Zimmermann (2007). The Economic Impact and Appropriate Management of Selected Invasive Alien Species on the African Continent. Global Invasive Species Program. 